\title{
Critical reading perceptions and practices of English First Additional Language learners in Gauteng, Tshwane South district
}

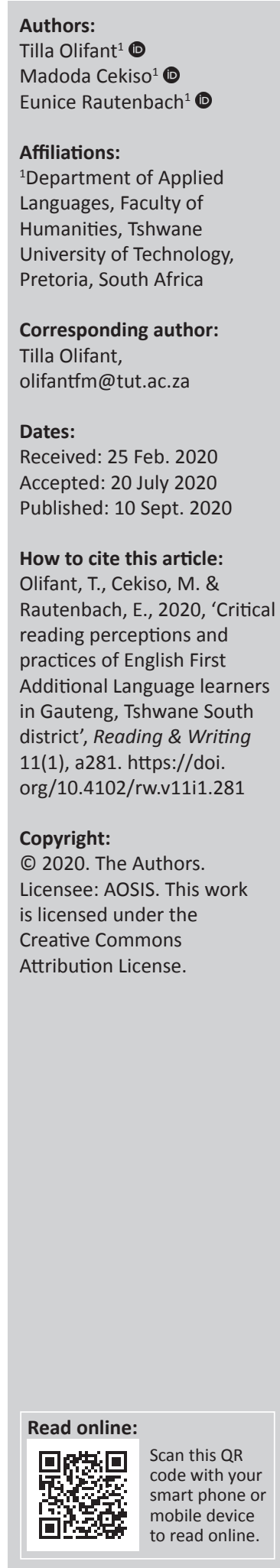

Background: Apart from being a knowledge-gaining commodity, critical literacy is believed to be a practice that exists between people, groups and communities in a sociopolitical and cultural context. It is assumed that without strong literacy skills, post-secondary education and employment options are limited. It is thus against this background that this investigation focused on the critical reading perceptions and practices of Grade 8 English First Additional Language (FAL) learners from two high schools in Gauteng, Tshwane South district.

Objective: The study investigated Grade 8 learners' critical reading self-perceptions and practices in the English FAL classroom.

Method: A quantitative research approach based on a non-experimental descriptive design was used. The purposively selected research sample consisted of 166 Grade 8 English FAL learners from two high schools in Gauteng, Tshwane South district. Data were collected through the use of a survey questionnaire, as well as a critical reading comprehension activity measurement and evaluation instrument. The Statistical Package for the Social Sciences (SPSS) version 25 was used to analyse data solicited through the survey questionnaire and reading comprehension activity. Specifically, the Spearman's correlation coefficient of variables was used to indicate if there was any relationship between the learners' reading perceptions and their reading practices.

Results: The results showed that although learners' self-perceptions indicated that they could critically analyse texts, the critical reading comprehension activity measurement and evaluation instrument revealed that learners were unable to apply most of the critical reading strategies they claimed to be using. Thus, learners' perception about their critical reading ability was not automatically an accurate indicator of their actual reading practice ability.

Conclusion: The findings from this study re-emphasise the reading crisis that is prevalent within the South African reading literacy landscape. A devastating conclusion that was arrived at, was that because learners did not engage critically in classroom reading, the Grade 8 English FAL learners from the participating schools contributed to the existing reading crisis in South Africa.

Keywords: critical reading; critical reading self-perception; critical reading practices; literacy; Tshwane.

\section{Introduction}

The importance of reading for learners' academic success, has been emphasised by various authors (Ameyaw \& Anto 2018; Bigozzi et al. 2017; Ecole Globale 2018; Pretorius 2010; Suacillo et al. 2016). However, there is considerable research supporting the claim that South Africa has a reading crisis. The current crisis regarding South African learners' poor reading proficiency is well documented in academic papers, government reports and the media (Howie et al. 2012; Olifant, Rautenbach \& Cekiso 2017; Rule \& Land, 2017; Spaul 2016; Van der Berg 2008). Subsequently, in South Africa, the critical reading development of learners' levels of critical reading instruction remains a challenge that still needs to be effectively addressed (Department of Education [DoE] 2003, 2005; Moloi \& Strauss 2005; Pretorius \& Mampuru 2007). In addition, the findings of the South African 2006, 2011 and 2016 Progress in International Reading Literacy Study (PIRLS), based on Grade 4 and Grade 5 Intermediate Phase learners revealed that learners had challenges with their literacy development in relation to thinking and reasoning abilities needed for reading to learn in their later years of schooling. Spaul (2016) asserts that the PIRLS 2016 results revealed that South African Intermediate Phase learners could not locate and retrieve explicitly stated information, actions and ideas from text. 
The above mentioned South African reading crisis indicates that South African learners lack critical reading skills. This idea is supported by Kurland (2000) who asserts that a genuine and substantial acquisition of knowledge requires more than the regular reading ability, but rather that of critical reading, which translates into increased critical thinking, deeper reader comprehension and more effective analytical writing. Therefore, this study was conducted to respond to the reading crisis already mentioned above. In order to examine the root cause of the problem, we felt it significant to explore learners' critical reading perceptions and practices. The choice of the two variables (critical reading perceptions and practices) was informed by the authors' curiosity to understand learners' beliefs about their knowledge of critical reading. We also felt it appropriate not only to rely on the learners' beliefs about the critical reading but also to take the study further by examining their practices. In this study, perception means the ability to become aware of, understand and interpret something and practice refers to the actual doing or using of something. In a South African context, the literature we reviewed revealed that there are no studies conducted that sought to compare learners' critical reading perceptions with their critical reading practices.

Therefore, the study was guided by the following research questions:

- What are the learners' perceptions of critical reading?

- What are the learners' critical reading practices?

- Is there any relationship between the learners' perceptions of critical reading and practices?

\section{Purpose of the study}

Critical reading practices are of critical importance in school, because they allow the learners to think, read and write critically about themselves, their situations and their environment within the classroom space (Norris, Lucas \& Prudhoe 2012:2). However, despite the fact that some studies on topics related to critical reading have been conducted in South Africa, literature reveals that few studies have been conducted on critical reading practices in a South African context. It is for this reason that this study sought to explore the critical reading perceptions and practices of Grade 8 English First Additional Language (FAL) learners from two high schools in Gauteng, Tshwane South district. Furthermore, the study sought to understand learners' reading perceptions since they can be more useful in explaining their reading practices than the well-intentioned inferences sometimes made by teachers (Nind et al. 2019). Having this information is likely to assist teachers to prepare informed critical reading intervention programmes for their learners.

\section{Literature review \\ Critical reading}

The concept of 'critical reading' refers to the process of understanding print material and attaching meaning to it
(Pretorius \& Ribbons 2005). Vaseghi, Gholami and Barjestech (2012:406) signify that critical reading is about thinking, that is, cogitating, while reading. Similarly, Bobkina and Stefanova (2016:681) expound that critical reading refers to the ability to interpret a text and make various inferences about it, in a manner that can elicit different conclusions. Therefore, to read critically is to engage in the act of reading with a questioning mind which will result in the comprehension, evaluation and decision to accept or reject what was read. It is in this light that Graves, Juel and Graves (1998) allude to the fact that comprehension (that is, critical reading of text) involves the ability to interpret the written word, the ability to conceptualise meaning from the text, the ability to understand the intention of the author, being aware of the theme of the text, and the ability to use language to create special effects.

Pretorius and Machet (2004:129) assert that literacy, specifically reading literacy, forms the backbone of scholastic success at all school levels. In fact, learners need to be equipped with the ability to read and, even more so, to be critically literate. This is necessary, so that they can meet the economic, social, cultural, digital and political demands of a rapid globalisation era (Naidoo, Dorasamy \& Reddy 2012:556). This means that reading literacy and critical engagement with texts at school level, specifically at secondary school level, as is applicable in this study, need to keep abreast of the increased demands for critical literacy skills in employment environments. Yet, South African learners fail to demonstrate independent learning from reading (Pretorius 2002:99).

The role of the reader, as Lerner (2001:99) argues, 'is to identify him/herself with the author or to be against him/her [i.e. against the author] taking a position, assuming a critical stance towards the reading'. In other words, it requires a critical mind and a critical eye to understand, interpret, identify, agree with or contradict written material. Accordingly, the researchers of this article points out that critical reading is a form of comprehension that enables the reader to identify and recognise their personal and social connotations in the written material, without literally reading them in the text.

Researchers such as McLaughlin and DeVoogd (2004) and Molden (2007) assert that critical reading, a constituent of critical literacy, thus involves asking questions to analyse the terminology, concepts and purpose of the text, identifying elements of argument introduced by the author, evaluating the evidence and credibility of the content of the text and positioning the reader in relation to the text. Ultimately, critical reading is an act that can help to empower learners to be able to distinguish among the various relationships, discriminations, inequalities and injustices in a text and transfer that knowledge to their daily lives. Consequently Raman, Sharma and Collins (2013:261) claim that the improvement of reading competency, which constitutes critical reading, is possible, but only through the effective and regular application of reading strategies. Özkan Gürses 
and Bouvet (2016) are of the view that the recognition of the critical role of reading strategy awareness in the reading process has also prompted several studies to focus on language learners' perceived use of reading strategies and reading ability. Subsequently, studies conducted by Alhaqbani and Riazi (2012), as well as Sheory and Mokthari (2001) have found a relationship between learners' perceived use of reading strategies and self-rated reading ability. However, the results of studies conducted by Alsamadani (2009) and Mónos (2005) provide contrary findings. They reveal that the perceived use of reading strategies did not significantly correlate with reading ability as measured by a reading comprehension test. The authors of the current study felt that since the results in literature contradict, there is room for a study that investigates the critical reading perceptions and reading practices of English FAL learners.

\section{Learners' perceptions of critical reading}

According to the Cambridge English Dictionary, perception refers to a belief or opinion often held by many people, and is based on how things seem. Research has shown that learners' perceptions influence their behaviour and willingness to learn (Nind et al. 2019; Portnov-Neeman \& Barak 2013). Similarly, Karasakaloglu, Saracaloglu and Yilmaz Ozelci (2012) argue that one of the major factors enabling critical reading is reader self-perception. In addition, Guthrie, Coddington and Wigfield (2009), as well as Usher and Pajares (2008) state that how learners perceive their own ability matters considerably to their academic achievement, to their persistence and motivation in school-related tasks. In support of this view, Hall (2009) asserts that negative perceptions of reading ability are destructive as they can discourage the students from reading. On the other hand, Guthrie et al. (2009) declare that positive reading perceptions appear to encourage learners to read a variety of material and also establish a wide range of reading purposes. Thus, learners' critical reading perceptions is important in order for them to develop a positive reading perception. The authors in the current study believe that teachers have an important role to play in order to assist learners to develop a positive reading perception.

The literature on students' reading perceptions has revealed that the majority of studies have been conducted at the university level. For example, Karasakaloglu, Saracaloglu and Yilmaz Ozelci (2012) conducted a study that sought to determine student teachers' perceptions they hold of their own critical reading. The results of their study showed that student teachers' beliefs about their critical reading differed according to gender and graduate programme but did not differ across grade levels. Karadag (2014) conducted a similar study whose aim was to explore primary school teachers' views of their critical reading skills and their perceptions of competence. The results revealed that the primary school teacher candidates did not consider themselves critically literate and they were not aware of how to use critical reading strategies.
Considering the above accounts regarding learners' perceptions in terms of critical reading, it is understood that a critical reading ability requires an individual to have a positive perception concerning the task of reading.

\section{Learners' critical reading practices}

Critical reading practices and reading comprehension processes are interrelated. Mullis et al. (2009) point out that the practice of critical reading, or comprehension activities, employs a repertoire of experience, background knowledge, linguistic and cognitive skills, as well as metacognitive capabilities, to attach meaning to the text. Similarly, Fleming (2020) points out that learners' practice of critical reading is the process of analysing and evaluating a text as they read, or as they cogitate about it after reading. Consequently, it appears that critical reading practices require learners to read the written word with a questioning approach, which is likely to promote their interpretation, evaluation and acceptance or rejection of the text. Succinctly, a learner's critical reading practice is established by the ability to interpret, evaluate, authenticate and form an opinion about a text. In other words, when learners engage in critical reading practices, they are required to read with a critical mind and a critical eye to understand, interpret, identify, accept or reject written material.

Apart from learners' ability to critique, assimilate and challenge texts, critical reading practices are instrumental in real-life situations. Janks (2010:21) approaches the reading process from three perspectives: (1) decoding, (2) reading with the text and (3) reading against the text. Janks explains that 'decoding' signifies linguistic knowledge and the proficiency of the written word. 'Reading with the text' denotes interpreting the written word by attaching one's own meaning, ideas and values to the text. 'Reading against the text' refers to the critiquing of the text that provides a deeper insight into the word, by combining individual and social knowledge and experiences with the possibility of promoting, challenging or disregarding the ideological effects of the text. Ultimately, it is this critical engagement with the text that constitutes learners' critical reading practices, which are essential life tools for academic success and a journey of lifelong learning.

To illustrate learners' critical reading practices, Zin, Eng and Rafik-Galea (2014:45-52) conducted research on 295 firstyear and second-year English FAL learners from various fields of study in a Malaysian university. Through the formulation of critical reading questions, the study explored learners' analytical ability by identifying the author's purpose and the main idea in the text. The study found that $66 \%$ of the participating learners failed to identify the author's intention with the text. Only $34 \%$ of the learners could identify the main idea correctly in the text. The learners' inability to determine the author's purpose with the text accurately, according to Zin et al. (2014:49), indicated that they (i.e. the learners) were unable to interpret the text. These results indicated that many of the participating 
learners lacked analytical and inference skills. Overall, the learners demonstrated a critical reading inability.

In summary, critical reading is explored as a practice that delves into a text, to recognise and understand the deeper abstract strata that exist within a piece of writing. Konza (2010:6) confirms this explanation when she asserts that the culminating goal of critical reading practices is to 'read between the lines', but also beyond the lines.

\section{The relationship between learners' critical reading perceptions and practices}

A learner's perception of their own critical reading ability could possibly serve as an indicator for their actual critical reading ability. Understanding learners' self-perception of their reading ability and their actual ability has prompted several studies over the years. For example, research by Alhaqbani and Riazi (2012), Mónos (2005), and Sheorey and Mokhtari (2001) found that there is a correlation between learners' critical reading practices and their self-perceived ability. Furthermore, a relationship is also likely to exist between learners' self-rated ability (which is based on their self-perception) and their actual critical reading practices as measured and evaluated by a comprehension activity (Barnett 1988; Madhumathi \& Ghosh 2012; Saeedeh 2013).

Contrary to the existing relationship between learners' reading self-perceptions and their actual critical reading practices mentioned above, research findings from studies conducted by Alsamadani (2009) and Mónos (2005) indicate that learners' self-perception is not necessarily an accurate indicator of their reading practice ability. This sentiment is supported by research conducted by Özkan Gürses and Bouvet (2016). These researchers measured and evaluated the relationship between university students' perceived use of reading strategies against their actual critical reading practices by means of a comprehension test. The results of this study established that 'negative correlations were found between perceived use of reading strategies and reading comprehension for all participants' (Özkan Gürses \& Bouvet 2016:30). Furthermore, the results of a study conducted by Smit, Gilmore and Jameson (2012:205) demonstrated that the relationship between self-perception and achievement only accounts for $2 \%$ of the variance in achievement. These researchers argue that the reason for this is because learners might not have a good understanding of their own reading ability.

Thus, the relationship between the self-perception of a learner and their actual critical reading practices is not that straightforward, neither should it be assumed that it is a correspondingly aligned relationship. In other words, when a learner has a positive critical reading self-perception, it is not an automatic indication that the learner will demonstrate positive critical reading practices. The contrasting findings of the relationship between learners' self-perceptions and their reading practices render further research into the phenomenon as necessary.

\section{Methodology}

This section deals with the research approach and design, an outline of the data collection procedure and instrumentation, and presentation of the data analysis process.

\section{Research approach and design}

A quantitative approach was used for the analysis of the study. According to Maree (2007:145), quantitative research is a process that is systematic and objective in its ways of using numerical data from only a selected subgroup of a universe (or population) to generalise the findings to the universe that is being studied. In addition, Leedy (1993) states that a quantitative method deals with data that are principally numerical. In the current study quantitative research was used to answer questions about the relationships between learners' reading perceptions and their practices. A correlational analysis was also employed within the quantitative method. Sousa, Driessnack and Costa Mendes (2007) point out that correlational analysis measures a relationship between two variables without the researcher controlling either of them. As already mentioned above, the two variables that were measured in the current study are learners' reading perceptions and their practices.

\section{Participants}

A total of 166 Grade 8 English FAL learners were purposively selected from the two chosen schools in Gauteng, Tshwane South district. Foley (2018) defines purposive sampling as a form of non-probability sampling in which researchers rely on their own judgement when choosing members of the population to participate in the study. In other words, researchers go to this community on purpose because they think that these individuals fit the profile of the people they need to reach. Regarding the current study, the researchers felt that the Grade 8 learners in the two selected schools could provide them with the relevant information with regard to their critical reading perceptions and their actual reading practices. The sample consisted of both boys and girls and their ages ranged from 13 to 15 years.

\section{Data collection and instrumentation}

The data collection process was conducted using the survey questionnaire and the critical reading comprehension activity.

The survey questionnaire consisted of two sections. Section A explored the demographic variables of the learners, whereas section B incorporated 44 items that related to the learners' critical reading practices.

The survey questionnaire instrument was used to obtain data about the learners' self-perceived ability to use critical reading strategies in the classroom. To assist the researchers to understand the learners' self-perceived and self-rated critical reading practices, the closed questions listed in Table 1 per critical reading strategy were asked. 
TABLE 1: Learners' self-perceived and self-rated ability to use critical reading strategies.

\begin{tabular}{|c|c|c|}
\hline Strategy & $\begin{array}{l}\text { Question } \\
\text { number }\end{array}$ & Question \\
\hline \multirow[t]{4}{*}{$\begin{array}{l}\text { Strategy 1: } \\
\text { Knowledge }\end{array}$} & 1 & $\begin{array}{l}\text { I can remember the information from a text that I } \\
\text { have read. }\end{array}$ \\
\hline & 2 & I can identify specific terms in a text. \\
\hline & 3 & I can identify main ideas in a text. \\
\hline & 4 & I can identify supporting details in a text. \\
\hline \multirow{8}{*}{$\begin{array}{l}\text { Strategy 2: } \\
\text { Comprehension }\end{array}$} & 1 & I can read and understand the title of a text. \\
\hline & 2 & $\begin{array}{l}\text { I can quickly read through long and difficult texts, } \\
\text { locating relevant details. }\end{array}$ \\
\hline & 3 & I can describe the main ideas in a text. \\
\hline & 4 & I can describe supporting details in a text. \\
\hline & 5 & $\begin{array}{l}\text { I can explain the meaning of words, or sentences from } \\
\text { the context. }\end{array}$ \\
\hline & 6 & I can find specific information from a text. \\
\hline & 7 & I can recognise a paraphrase. \\
\hline & 8 & $\begin{array}{l}\text { I can understand the relationships: } \\
\text { - within sentences. } \\
\text { - between sentences. }\end{array}$ \\
\hline \multirow{5}{*}{$\begin{array}{l}\text { Strategy 3: } \\
\text { Application }\end{array}$} & 1 & I can predict the outcomes of an article. \\
\hline & 2 & I can use the knowledge that I have when I read a text. \\
\hline & 3 & $\begin{array}{l}\text { I can use my personal experiences to improve my } \\
\text { understanding of a text when I read. }\end{array}$ \\
\hline & 4 & $\begin{array}{l}\text { I can read about an idea in a text and use it in other } \\
\text { situations that I read about. }\end{array}$ \\
\hline & 5 & $\begin{array}{l}\text { I can read about an idea in a text and use it to solve } \\
\text { problems in my own life. }\end{array}$ \\
\hline \multirow[t]{6}{*}{$\begin{array}{l}\text { Strategy 4: } \\
\text { Analysis }\end{array}$} & 1 & $\begin{array}{l}\text { When I read a text, I know the difference between a } \\
\text { fact and an opinion. }\end{array}$ \\
\hline & 2 & $\begin{array}{l}\text { When I read a text, I can show which points are } \\
\text { relevant to the topic written about. }\end{array}$ \\
\hline & 3 & $\begin{array}{l}\text { When I read a text, I can conclude what the text is } \\
\text { about. }\end{array}$ \\
\hline & 4 & $\begin{array}{l}\text { When I read a text, I can identify the reasons for } \\
\text { certain actions in the text. }\end{array}$ \\
\hline & 5 & $\begin{array}{l}\text { When I read, I can separate the idea within the text } \\
\text { into its different parts. }\end{array}$ \\
\hline & 6 & $\begin{array}{l}\text { When I read, I can identify similarities and } \\
\text { contradictions in a text. }\end{array}$ \\
\hline \multirow[t]{3}{*}{$\begin{array}{l}\text { Strategy } 5: \\
\text { Synthesis }\end{array}$} & 1 & $\begin{array}{l}\text { I can connect the ideas: } \\
\text { - within a paragraph. } \\
\text { - between paragraphs. }\end{array}$ \\
\hline & 2 & I can summarise information after reading a text. \\
\hline & 3 & I can draw conclusion after reading a text. \\
\hline \multirow[t]{8}{*}{$\begin{array}{l}\text { Strategy 6: } \\
\text { Evaluation }\end{array}$} & 1 & $\begin{array}{l}\text { I can decide on the trustworthiness of the information } \\
\text { in a text. }\end{array}$ \\
\hline & 2 & I can make a decisions on the argument when I read. \\
\hline & 3 & I can determine the strength of an idea in a text. \\
\hline & 4 & I can determine the weakness of an idea in a text. \\
\hline & 5 & I can determine the relevancy of an idea in a text. \\
\hline & 6 & $\begin{array}{l}\text { I can identify and explain writers': } \\
\text { - views in a text. } \\
\text { - attitudes in a text. } \\
\text { - intentions in a text. }\end{array}$ \\
\hline & 7 & $\begin{array}{l}\text { I can determine the trustworthiness of sources in a } \\
\text { text. }\end{array}$ \\
\hline & 8 & I can draw conclusion after reading a text. \\
\hline \multirow{5}{*}{$\begin{array}{l}\text { Strategy 7: } \\
\text { Discourse for } \\
\text { social action }\end{array}$} & 1 & I can discuss the content of a text effectively. \\
\hline & 2 & I can discuss the text, after reading it. \\
\hline & 3 & $\begin{array}{l}\text { I can use the lesson learnt from a text to improve my } \\
\text { own life. }\end{array}$ \\
\hline & 4 & $\begin{array}{l}\text { I can use the information from a text to decide what is } \\
\text { wrong and what is right in life. }\end{array}$ \\
\hline & 5 & $\begin{array}{l}\text { I can use the information learnt though the reading of } \\
\text { text in school, to make decisions outside of the school. }\end{array}$ \\
\hline
\end{tabular}

The questionnaire contained opinion statements that were closed questions, which were measured on a four-point Likert scale: (1) Never, (2) Sometimes, (3) Most of the time and (4) Always. These intensity scales were used to simplify the procedure of data processing and to obtain uniformity. Furthermore, the opinion statements were kept simple, relevant and precise so that each learner could understand. The questionnaire was distributed among the 166 learners from the two high schools asking them for self-ratings on their self-perceived critical reading ability.

The critical reading comprehension activity was used as a grade-appropriate comprehension activity to explore and understand how Grade 8 English FAL learners engage with text through a critical reading lens. This activity was used to measure and evaluate the learners' critical reading performance in the classroom. Furthermore, this process enabled the researchers to explore the relationship between the learners' perceptions of their own critical reading and the actual status of their critical reading practices.

The critical reading comprehension activity was used as a systematic way of gathering information about the critical reading practices of the Grade 8 learners and expressing this information in numerical form (Imenda \& Muyangwa 2000:148). Similarly, White (2005:164) explains that a test is a 'systematic procedure' in which the researcher presents the participants with a set of constructed stimuli. The researchers thus allocated a numeral to the participants based on their response to the stimuli. This assigned numeral was then used to make inferences about the ability of the respondents regarding what the test was supposed to assess.

The framework of the critical reading comprehension passages was followed by 20 questions that measured and evaluated learners' application ability of the six critical reading strategies namely: (1) Knowledge, (2) Comprehension, (3) Application, (4) Analysis, (5) Synthesis and (6) Evaluation. The critical reading strategies measured and evaluated by the critical reading comprehension activity were aligned with the critical reading perception questions in the survey questionnaire. The critical reading comprehension activity addressed a contemporary issue, which the learners could relate to. For example, the title of the reading comprehension was 'Emoji invasion'. This comprehension activity was sourced from the National Curriculum and Assessment Policy Statement (CAPS) teaching and learning material, to ensure that the South African curriculum guidelines were adhered to. In this way, the scoring of the learners' critical reading practices was conducted on a justifiable basis.

\section{Data analysis}

To meet the objectives outlined in this study, Statistical Package for the Social Sciences (SPSS) version 25 was used for the analysis. Specifically, the application of the two-way mixed analysis of variance (ANOVA) was used to statistically analyse the data obtained from: (1) the questionnaire instrument and (2) the critical reading comprehension activity. The survey 
questionnaire data were analysed by determining the overall means and standard deviations of the learners' self-rated critical reading perceptions, whereas the critical reading comprehension activity data were analysed based on the percentage scores obtained by the research participants. The data were visually displayed in tables using frequencies and percentage scores, whereafter they were summarised with data descriptions and interpretations. This process was aligned with White's (2005:98) declaration of a non-experimental, correlation design which qualifies the analysis and accurate description of variables that influence the topic under investigation, such as the critical reading self-perceptions and practices of Grade 8 English FAL learners.

The ANOVA enabled the researchers to compare the survey questionnaire results with the critical reading comprehension activity measurements and evaluation instrument. Using ANOVA also aided the researchers to establish whether the comparisons reflected by the results of the survey questionnaire and the comprehension activity measurements and evaluation instrument were significant.

\section{Findings}

The findings as reported by the questionnaire and the critical reading measurement and evaluation instruments are presented in the following section.

\section{Learners' perceptions of critical reading}

The findings of the learners' perceptions of their critical reading ability were established with the survey questionnaire and recorded in Table 2, which shows that most learners believed that they could use the knowledge critical reading strategy with a mean score of 2.64. The critical reading strategy application generated a mean rating of 2.59 , followed by the analysis strategy with a mean score of 2.53 and the perceived ability to be able to comprehend a text published a mean value 2.51 . Although the critical reading strategy synthesis produced the second least perceived ability score with a mean of 2.41, the least number of the learners indicated that they could evaluate a text and consequently it reflected the lowest mean value of 2.39. Critical reading dialogue produced a mean value of 2.94

Considering the learners' self-perceived and self-rated critical reading abilities reflected by the survey questionnaire, it appeared that the critical reading strategy that learners

TABLE 2: Learners' self-perceived and self-rated ability to use critical reading strategies based on the questionnaire instrument.

\begin{tabular}{lccccc}
\hline Strategy & $\boldsymbol{N}$ & Minimum & Maximum & Mean & $\begin{array}{c}\text { Standard } \\
\text { deviation }\end{array}$ \\
\hline Knowledge & 165 & 1.50 & 4.00 & 2.6424 & 0.51444 \\
Comprehension & 166 & 1.44 & 4.56 & 2.5173 & 0.50749 \\
Application & 165 & 1.00 & 3.80 & 2.5927 & 0.51381 \\
Analysis & 165 & 1.33 & 4.00 & 2.5363 & 0.52310 \\
Synthesis & 163 & 1.00 & 4.00 & 2.4059 & 0.59527 \\
Evaluation & 166 & 1.40 & 5.40 & 2.3887 & 0.56974 \\
Critical reading dialogue & 166 & 1.75 & 4.00 & 2.9403 & 0.54168 \\
\hline
\end{tabular}

perceive themselves to use best, is the critical reading dialogue strategy. The reason could be that this strategy is normally used by teachers who apply traditional methods in teaching reading. Sometimes, even teachers who are not aware of different reading strategies unconsciously make use of this strategy. However, the learners indicated that they were least able to use the evaluation critical reading strategy.

Through the questionnaire data, which reflected the lowest mean score for the evaluation critical reading strategy, it thus emerged that the learners had little confidence in their ability to evaluate a text, with the intent to improve their lives inside and outside of school. This can be concluded from the lowest recorded mean score of 2.39. In other words, most learners indicated that they were unable to evaluate a text. This situation worried the researchers since evaluating information encourages one to think critically about the reliability, validity, accuracy, point of view or bias of information. According to Bloom's Taxonomy, evaluation is the final level where learners make judgements about the value of ideas. Despite the importance of this critical reading strategy, learners were found wanting as far as its application is concerned.

\section{Learners' critical reading practices}

The critical reading comprehension activity measurement and evaluation instrument was used to obtain data about learners' actual critical reading practices (i.e. their measured and evaluated ability) when they critically engage with texts. Table 3 reflects the critical reading strategies used as a strategic framework to determine the learners' actual critical reading ability. Considering the data reflected in this table, it was clear that learners mostly knew how to apply the knowledge and comprehension critical reading strategies, which signifies the most basic type of meaning extraction from reading. However, the learners struggled to read beyond the lines. The findings as reported by the comprehension activity measurement and evaluation instrument in Table 3 demonstrate that the learners were challenged to apply critical reading strategies that internalise, analyse and evaluate the content of the text in a comprehension activity. From the six critical reading strategies used in the comprehension activity measurement and evaluation instrument, the percentage scores produced by evaluation critical reading strategy were among the lowest results. The evaluation critical reading strategy percentage scores of $34.3 \%$ and $29.5 \%$ obtained by learners illustrated that learners lacked the ability to judge and critique a text.

The comprehension activity critical reading measurement and evaluation instrument presents the classroom critical reading practice performance percentage scores of Grade 8 English FAL learners.

Regarding question 1, which assessed whether learners could apply the knowledge critical reading strategy, $76.4 \%$ of the learners reflected the ability to select the correct title 
TABLE 3: Comprehension activity measurement and evaluation instruments reflecting the learners' critical reading practices as scores obtained $(N=166)$.

Questions and statement questions measuring and evaluating Score of learners the learners' application of the critical reading strategies as indicating their per reading text.

\section{Knowledge}

Critical reading strategy: Knowledge assessed by the following question:

Q1: Choose the correct title of the text from the following options.

\section{Comprehension}

Critical reading strategy: Comprehension assessed by the following six (6) questions:

Q2: State who do you think this article was written for: 72.1

Q6: Summarise the text in one of the following sentences. 54.8

Q8: The picture used in the text tells us more about: $\quad 27.4$

Q11: From the following sentence, which one best describes the $\quad 34.3$

main idea of the text'?

Q13: Which of the following explanations best explains this

expression?

Q18: Within the context of the sentence, determine the meaning 22.5 of the word 'ambiguity'.

\section{Application}

Critical reading strategy: Application assessed by the following three (3) questions:

Q3: Identify whether the following statement is true or false.

Q5: Reflect on the text and select one of the following statements

Q7: Reflect on the text and identify the factors that assist a speaker 64.9

to appear confident

4. Analysis

Critical reading strategy: Analysis assed by the following five (5) questions:

Q4: Explain the lesson which you have learned from reading the text.

Q9: Predict what might happen when you use the worn emoji

Q14: Distinguish whether the following statement is a fact or an

opinion.

Q15: What conclusion can be made when you analyse the sound of the word 'emoji'?

Q19: How can you possibly apply the lesson learned from this passage when you text?

\section{Synthesis}

Critical reading strategy: Synthesis assessed by the following three (3) questions

Q10: Do you agree that it is important to know how to use emojis

Q12: Create a new title for the text by selecting the most suitable option from the following list.

Q20: Which of the following phrases can you use to create another

\section{Evaluation}

Critical reading strategy: Evaluation assessed by the following two (2) questions:

Q16: In your opinion, what do you think is the author's purpose in

for a text. That means that most learners could apply the knowledge critical reading strategy when reading texts.

The comprehension critical reading strategy was measured by questions 2, 6, 8, 11, 13 and 18. Altogether $72.1 \%$ of learners demonstrated that they could determine the target audience of a text and $54.8 \%$ indicated that they could summarise a text. However, a mere $27.3 \%$ said that they could read from a picture what a text was about. Learners also performed poorly in describing the main idea in a text (34.3\%), as well as determining unknown words within the context of a text (22.5\%). Some of the comprehension percentage scores clearly revealed that learners experience challenges with critical reading practices in class. Although there were learners who

could comprehend when reading, there were also those learners who were challenged to read with understanding.

From the three questions asked in the comprehension activity to measure and evaluate the application of critical reading strategy, learners could only respond successfully to one of the questions with a percentage score of $64.9 \%$. Yet for the other two questions, only $25.0 \%$ and $32.1 \%$ could record the correct answer to the questions. As with the comprehension critical reading strategy, it appeared that the majority of learners did not know how to apply a critical reading strategy when they critically engaged with the text.

To measure and evaluate the analyse critical reading strategy the percentage scores were as follows: about half of the learners $(50 \%)$ could explain the lesson which they had learnt from a text, while just more than half $(53 \%)$ could make a prediction when reading a text. However, in contrast, not even one-fifth of the number of learners (16.8\%) could identify the difference between a fact and an opinion. Most learners $(71.4 \%)$ demonstrated that they could draw conclusions from the sound of words; likewise $67.8 \%$ of learners were able to apply the lesson learnt from a text to their daily lives.

Although $44.7 \%$ of learners, that is less than half of the total number of learners, could not correctly agree or disagree with textual information as part of the synthesis critical reading application process, more than half of the learners $(65.7 \%)$ were able to create a suitable new title for the text and could also apply the synthesis strategy $(64.2 \%)$ by providing an alternative title associated with the text. Subsequently, many learners recorded an above-average ability to synthesise when reading a text.

From a sample group of $(N=166)$, only a few learners could apply the evaluation critical reading strategy. This was in response to the two questions measuring if learners could: (1) identify the authors' purpose for writing a text (34.35\%) and (2) identify textual evidence while reading (29.5\%). Most learners seemed to have difficulty evaluating a text when they read.

Critical reading practices are what the learners acquire as part of their classroom experience, and effective reading literacy practices are what ultimately prepare them for their lives beyond schooling.

\section{The relationship between learners' critical reading self-perceptions and actual critical reading practices}

A correlation, as Leedy and Ormrod (2010:183) explain, refers to establishing whether a relationship exists between two or more of the variables in the same sample group or between the same variables in two sample groups. The extent (i.e. the strength or the weakness) to which differences in one variable are related to the differences in one or more other variables can also be determined. In the context of this 
TABLE 4: Spearman's correlation coefficient of variables.

\begin{tabular}{|c|c|c|c|c|c|c|}
\hline Comprehension activity scores obtained & Knowledge & Comprehension & Application & Analysis & Synthesis & Evaluation \\
\hline Correlation coefficient & 0.269 & 0.190 & 0.089 & 0.079 & 0.164 & 0.126 \\
\hline Significance (two-tailed) & 0.000 & 0.014 & 0.258 & 0.315 & 0.037 & 0.107 \\
\hline
\end{tabular}

Note: Used to indicate any relationship between the learners' perceptions and their practices.

study, we established whether a relationship existed between the same variables (i.e. the critical reading strategies) in two sample groups (i.e. the survey questionnaire and the comprehension activity).

To further augment the reliability of the findings produced by this study, the researchers conducted a correlation analysis to establish whether any relationships were produced by the critical reading strategies as obtained in the learners' critical reading comprehension activity results, against the learners' perceptions of their own critical reading abilities, as portrayed by the percentage scores shown from the survey questionnaire. The critical reading strategies: (1) knowledge, (2) comprehension, (3) application, (4) analyses, (5) synthesis and (6) evaluation, were used as structural elements for both these instruments. The results are shown in Table 4.

The Spearman correlation coefficient $(r)$ was applied in this study. A Spearman correlation ranking of 0 indicates that there is no tendency for $\mathrm{Y}$ (example: the knowledge strategy practice ability) to either increase or decrease when $X$ (example: the knowledge strategy self-perception ability) increases or decreases. The ranking 0 thus indicates that there is no significant relationship. When $\mathrm{X}$ and $\mathrm{Y}$ are perfectly monotonically related, the Spearman correlation coefficient becomes 1 , indicating a strong and significant relationship. Based on this explanation, the results in Table 4 reflect the following three critical reading strategy relationships:

1. The knowledge critical reading strategy as perceived by the learners and reported by the survey questionnaire, compared to the percentage score obtained by the learners in the critical reading comprehension activity measurement instrument, reflected a positive significant correlation of $p=0.00<0.05$ (significant value criterion) with a small correlation coefficient value of 0.269 . There was a statistically significant, but practically small, correlation.

2. The comprehension critical reading strategy as perceived by the learners and reported by the survey questionnaire, compared to the percentage score obtained by the learners in the critical reading comprehension activity measurement instrument, reflected a positive significant correlation of $p=0.014<0.05$ (significant value criterion) with a small correlation coefficient value of 0.190 .

3. The synthesis critical reading strategy as perceived by the learners and reported by the survey questionnaire, compared to the percentage score obtained by the learners in the critical reading comprehension activity measurement instrument, reflected a positive significant correlation of $p=0.037<0.05$ (significant value criterion) with a small correlation coefficient value of 0.164 .
The establishment of only three significant value correlations based on the learners' self-perceived critical reading ability, compared to the scores obtained in the critical reading comprehension instrument which measured and evaluated the learners' actual critical reading ability, suggested that the learners had little understanding of their own critical reading ability.

The other three correlations proved to be insignificant, by reflecting no correlation between learners' critical reading self-perceptions and their actual critical reading ability.

Since the results produced by the comprehension activity critical reading measurement and evaluation instrument refuted the self-perceptions results generated by the survey questionnaire, it translated that no relationship existed between the learners' perceptions about their critical reading ability and their actual critical reading performance. This suggests that the learners had little understanding of their critical reading ability.

\section{Discussion}

The findings disclosed by the survey questionnaire indicated that the learners believed that they could apply critical reading strategies when they read in the English FAL classroom. However, the actual scores which they (that is, the learners) produced through the comprehension activity critical reading measurement and evaluation instrument indicated that many of the learners could not apply critical reading strategies in the classroom. As an example, in response to the two questions that measured and evaluated the evaluation critical reading strategy, only few learners, that is, 34.35 and $29.5 \%$ from a total number of 166 learners, could apply the evaluation critical reading strategy while reading. Yet, when they completed the survey questionnaire, the learners gave the impression that they were familiar with classroom critical reading practices.

Furthermore, although through the survey questionnaire, learners reported that they could analyse whether information is factual or opinionated, less than one-fifth of the learners, that is, $16.8 \%$ of learners, could identify the difference between a fact and an opinion in practice. The above result is confirmed by Wilson Devereux et al. (2004:1) who point out that there are several learners who cannot engage critically with academic texts. Comber (2006:51) points out that learners need to connect the content of a text that they read in class to what is happening in their lives. Contrary to this statement, learners demonstrated that they were not able to apply critical reading strategies. According to the sociocultural theory of literacy, learners are expected to embrace their own conceptual perspectives, and this enables 
them to more critically evaluate other aspects of their lives. Unfortunately, in the current study, learners did not reflect this ability.

Considering that knowledge was the critical reading strategy that the majority of learners, that is, $76.4 \%$, knew how to apply best, it confirmed that learners mostly only know how to apply basic reading strategies. Furthermore, the knowledge reading strategy reflected a correlation value $(r)$ of 0.269 in the survey questionnaire and the critical reading comprehension activity. This finding is confirmed by Burns, Roe and Ross (1999:219) who relate that literal comprehension signifies the most basic type of comprehension, which refers to the use of a basic reading strategy. In other words, the learners process information at face value, directly as it is stated in the text, by applying only basic reading strategies. The learners did not read beyond the lines.

Alvermann (2002:198) surmises that since the learners do not know how to position themselves as critical readers of texts, it is possible that they perceive themselves as critical readers of text, yet they are not. For this reason, it seems the learners experience a sense of misconception regarding their own critical reading ability.

Furthermore, the learners' self-perceived critical reading ability interpreted with the survey questionnaire compared to the results of the critical reading comprehension activity performance measurement and evaluation instrument contradicted each other. In other words, the learners perceived themselves to be able to apply critical reading strategies to the text, yet they were unable to effectively demonstrate this ability. Mokhtari and Reichards's (2002:249) statement that 'it is critically important that learners should be cognisant and monitor their own reading practices' is shown to be futile by these findings, because learners had a misconception about their own critical reading abilities. To put it differently, the learners did not monitor their own reading practices.

The results of the survey questionnaire indicated that the learners believed that they could apply most critical reading strategies when they read in the English FAL classroom. However, the actual scores that they (that is, the learners) produced through the comprehension activity critical reading measurement and evaluation instrument indicated that most of the learners could not apply critical reading strategies when reading in the classroom. Through the survey questionnaire responses, the learners gave the impression that they were familiar with critical reading strategies, but the comprehension activity performance measurement and evaluation scores reflected that learners were not able to apply all the critical reading strategies to a text.

In sum, the correlation comparisons of the critical reading strategies established by these two instruments revealed only three statistically significant, but practically small, correlations. The correlation coefficient of variables finding is aligned with the impression that learners' perception about their critical reading ability is not automatically an accurate indicator of their actual reading practice ability (Alsamadani 2009; Mónos 2005). Aligned with the findings of the research conducted by Alsamadani (2009) and Mónos (2005), the results of this study re-emphasised that learners do indeed have an inaccurate perception about their own reading practices.

\section{Conclusion}

The study sought to explore the critical reading perceptions and practices of English FAL learners in two schools in Gauteng. The results indicated that the learners had high self-perceptions about their reading ability. Their claim to be using a wide range of critical reading strategies raises questions about their awareness of critical reading strategies and their function in the process of reading to learn. However, the results further revealed that the learners' reading perceptions contradicted their actual reading practices in that in their classrooms they were not using the strategies they claimed to be using. Thus, this study played an important role in revealing the real position of learners in terms of their perceptions of critical reading. Subsequently, the authors felt that this situation calls for the English FAL teachers to help the learners to bridge the gap between their critical reading perceptions and their actual reading practices.

\section{Recommendations}

Although there are many challenges that learners face in the classroom, the findings disclosed that the learners' perceptions on critical reading practices are important for their sociocultural progress in and outside of the classroom. Subsequently, the findings and discussion of this study revealed the following implications for reading instruction, specifically critical reading instruction:

- Teachers should teach critical reading strategies either explicitly or implicitly. In that way learners are likely to be aware of a wider range of critical reading strategies. In addition, learners' critical reading motivation programme should be introduced by every English FAL teacher in collaboration with their learners, and the teacher should commit to support, acknowledge and compliment the learners for their initiation of and participation in classroom activities and discussions that promote critical reading practices. Acritical reading motivation programme will possibly enhance the learners' ability to monitor their own reading and stimulate a feeling of quiet satisfaction, which, in turn, can possibly increase their sense of self-efficacy, ultimately improving not only their selfperception, but their critical reading practices.

- Schools should embark on critical reading awareness campaigns that will sensitise learners to the difference between their perceptions and their critical reading reality. During these campaigns, learners should be exposed to a wide range of reading material. This process might initiate the redress of the critical reading self-perception and practice disparity. 
- Teacher-parent critical reading partnerships should be established by schools. Such a partnership may possibly amplify parental involvement and awareness in the critical reading practices of their children and, as a result, increase not only the chances of learners cultivating a critical stance and improving their critical reading practices, but also empower the learners to become critically literate citizens of the world.

\section{Acknowledgements Competing interests}

The authors have declared that no competing interest exists.

\section{Author's contributions}

All authors contributed equally to this work.

\section{Funding information}

This research received no specific grant from any funding agency in the public, commercial, or not-for-profit sectors.

\section{Ethical consideration}

This article followed all ethical standards for carrying out research without direct contact with human or animal subjects.

\section{Data availability statement}

Data sharing is not applicable to this article as no new data were created or analysed in this study.

\section{Disclaimer}

The views and opinions expressed in this article are those of the authors and do not necessarily reflect the official policy or position of any affiliated agency of the authors.

\section{References}

Alhaqbani, A. \& Riazi, M., 2012, 'Metacognitive awareness of reading strategy use in Arabic as a second language', Reading in a Foreign Language 24(2), 231-255. https://doi.org/10.1207/s15548430jlr3402_ 4

Alsamadani, H.A., 2009, 'The relationship between Saudi EFL college-level students' use of reading strategies and their EFL reading comprehension', PhD dissertation, viewed 10 February 2020, from https://etd.ohiolink.edu/rws etd/document/get/ ohiou1224685570/inline

Alvermann, D.E., 2002, 'Effective literacy instruction for adolescents', Journal of Literacy Research 34(2), 189-208.

Ameyaw, S. K. \& Anto, S.K., 2018, 'Read or perish: Reading habits among students and its effect on academic performance: A case study of Eastbank Senior High School, Accra', Library Philosophy and Practice (e-journal) 1748, viewed 23 January 2020 from https://digitalcommons.unl.edu/libphilprac/1748

Anderson, L.W. \& Krathwohl, D.R., 2001, A taxonomy for learning, teaching and assessing: A revision of Bloom's Taxonomy of educational objectives, Complete edition, Longman, New York, NY

Barnett, M.A., 1988, 'Reading through context: How real and perceived strategy use affects L2 comprehension', The Modern Language Journal 72(2), 150-162. doi: 10.1111/j.1540-4781.1988.tb04177.x

Bigozzi, L., Tarchi, C., Vagnoli, L., Valente, E. \& Pinto, G., 2017, 'Reading fluency as a predictor of school outcomes across grades', Frontiers in Psychology 8(200), 1-9. https://doi.org/10.3389/fpsyg.2017.00200

Bloom's Taxonomy-evaluating category, viewed 03 June 2020, from https://www. thoughtco.com/blooms-taxonomy.
Bobkina, J. \& Stefanova, S., 2016, 'Literature and critical literacy pedagogy in the EFL classroom: Towards a model of teaching critical thinking skills', SSLLT 6(4), 677-696. https://doi.org/10.14746/ssllt.2016.6.4.6

Burns, P.C., Roe, B.D. \& Ross, E.P., 1999, Teaching reading in today's elementary schools (7th edn.), Houghton Mifflin, Boston, MA.

Cambridge English Dictionary, viewed 03 Feburary 2020, from https://dictionary cambridge.org/dictionary/english

Comber, B., 2006, 'Pedagogy as work: Educating the next generation of literacy teachers', Pedagogies 1(1), 59-67. https://doi.org/10.1207/s15544818ped0101_9

Department of Education (DoE), 2003, Systemic evaluation foundation phase mainstream national report, DoE, Pretoria.

Department of Education (DoE), 2005, Grade 6 intermediate phase systemic evaluation report, DoE, Pretoria. viewed 18 January 2020, from http://www. education.gov.za/LinkClick.aspx?fileticket=XmIJ

Ecole Globale, 2018, Importance of reading books in a student life, viewed 22 February 2020, from https://www.ecoleglobale.com/blog/importance-of-books-in-studentlife/

Fleming, G., 2020, What does critical reading really mean? Thought-Co, viewed 11 February 2020, from thoughtco.com/critical-reading-basics- 1857088

Foley, B., 2018, Purposive sampling 101, viewed 17 February 2020, from https://www. surveygizmo.com/resources/blog

Graves, M.L., Juel, C. \& Graves, B.B., 1998, Teaching reading in the 21st century, Allyn and Bacon, Boston, MA.

Guthrie, J.T., Coddington, C.S. \& Wigfield, A., 2009, 'Profiles of reading motivation among African American and Caucasian students', Journal of Literacy Research 41(3), 317-353. https://doi.org/10.1080/10862960903129196

Hall, L., 2009, 'Struggling reader, struggling teacher: An examination of studentteacher transactions with reading instruction and text in social studies', Research in the Teaching of English 43(3), 286-309.

Howie, S.J., Van Staden, S., Tshele, M., Dowse, C. \& Zimmerman, L., 2012, PIRLS 2011 South African children's reading literacy achievement summary report, Centre of Evaluation and Assessment: University of Pretoria, Pretoria.

Imenda, S.N. \& Muyangwa, M.M., 2000, Introduction to research in education and behavioural sciences, Einmed Publishers, Umtata.

Janks, H., 2010, Literacy and power, Routledge, New York, NY.

Karadag, R., 2014, 'Primary school teacher candidates' views towards critical reading skills and perceptions of their competence', Procedia-Social and Behavioura Sciences 152, 889-896. https://doi.org/10.1016/j.sbspro.2014.09.339

Karasakaloglu, N., Saracaloglu, S.A. \& Yilmaz Ozelci, S., 2012, 'Primary school teachers' critical reading self-efficacy perceptions', Mustafa Kemal Universitesi Sosya Bilimler Enstitusu Dergisi 9(19), 405-422.

Konza, D., 2010, 'Understanding the reading process', Research Into Practice-Literacy Secretariat, Government of South Australia, Adelaide.

Kurland, D., 2000, 'How the language really works: The fundamentals of critical reading and effective writing', viewed 22 February 2020, from http://www. criticalreading.com/critical-thinking.htm

Leedy, P. D. 1993. Practical research: Planning and design. $5^{\text {th }}$ ed. New York: Mc Millan

Lerner, D., 2001, Leer y escribir en la escuela: lo real, lo posible y lo necesario, Fondo de cultura económica, México.

Madhumathi, P. \& Ghosh, A., 2012, 'Awareness of reading strategy use of Indian ESL students and relationship with reading comprehension achievement', English Language Teaching 5(12), 131-140. https://doi.org/10.5539/elt.v5n12p131

Maree, K., 2007, First steps in research, Van Schaik Publishers, Pretoria.

Mclaughlin, M. \& Devoogd, G. 2004a. Critical literacy as comprehension: Expanding reader response. Journal of Adolescent and Adult Literacy 48(1), 52-63.

Mclaughlin, M. \& Devoogd, G., 2004b, Critical literacy: Enhancing students' comprehension of text, Scholastic, New York, NY.

Mokhtari, K. \& Reichard, C.A., 2002, 'Assessing students' metacognitive awareness of reading strategies', Journal of Educational Psychology 94(2), 249-259. https://doi. org/10.1037/0022-0663.94.2.249

Molden, J., 2007, 'Critical literacy: The right answer for the reading classroom. Strategies to move beyond comprehension for reading improvement', Reading Improvement 44(1), 50-56.

Moloi, M. \& Strauss, J., 2005, 'A study of the conditions of schooling and the quality of education', South Africa working report, SACMEQ and the Ministry of Education, Harare and Pretoria.

Mónos, K., 2005, 'A study of the English reading strategies of Hungarian university students with implications for reading instruction in an academic context', Malaysian Journal of ELT Research, Inaugural Volume 1-23, viewed 28 February 2020, from http://www.melta.org.my/Doc/MonosK_Eng_reading_strategies.pdf

Mullis, I.V.S., Martin, M.O., Kennedy A.M., Trong, K.L. \& Sainsbury, M., 2009, PIRLS 2011 Assessment framework. TIMSS and PIRLS International Study Center, Boston, MA.

Naidoo, U., Dorosamy, K. \& Reddy, S., 2012, 'Perceptions of educators of reading literacy: A case study of the intermediate phase in South African primary schools', Journal of Economics and Behavioural Studies 4(10), 555-569. https://doi. org/10.22610/jebs.v4i10.357

Nind, M., Holmes, M., Insenga, M. \& Sutton, C., 2019, 'Student perceptions on learning research methods in the social sciences', Teaching in Higher Education. https://doi.org/10.1080/13562517.2019.1592150 
Norris, K., Lucas, L. \& Prudhoe, C., 2012, 'Preparing preservice teachers to use critical literacy in the early childhood classroom', Multicultural Education 19(2), 59-62.

Olifant, F.M., Rautenbach, E. \& Cekiso, M.P., 2017, 'Reading habits and attitudes of grades 8-10 learners toward English second language in Eersterust', Journal for Language Teaching 51(2), 35-57. https://doi.org/10.4314/jlt.v51i2.2

Özkan Gürses, M. \& Bouvet, E., 2016, 'Investigating reading comprehension and learning styles in relation to perceived use of reading strategies', Reading in a Foreign Language 28(1), 20-42.

Portnov-Neeman, Y. \& Barak, M., 2013, 'Exploring students' perceptions about learning in school: An activity theory based study', Journal of Education and Learning 2(3), 9-24. https://doi.org/10.5539/jel.v2n3p9

Pretorius, E.J., 2002, 'Reading ability and academic performance in South Africa. Are we fiddling while Rome is burning?', Language Matters 33(1), 169-196. https:// doi.org/10.1080/10228190208566183

Pretorius, E.J., 2010, 'Issues of complexity in reading: Putting Occam's razor aside for now', Southern African Linguistics and Language Studies 28(4), 339-356.

Pretorius, E.J. \& Machet, M.P., 2004, 'Literacy and disadvantage: Enhancing learner's achievements in the early primary school years', African Education Review 1(1), 128-146. https://doi.org/10.1080/18146620408566274

Pretorius, E.J. \& Mampuru, D.M., 2007, 'Playing football without a ball: Language, reading and academic performance in a high-poverty school', Journal of Research in Reading 30(1), 38-39. https://doi.org/10.1111/j.1467-9817.2006. 00333.x

Pretorius, E.J. \& Ribbons, R., 2005, 'Reading in a disadvantaged high school: Issues of accomplishment, assessment and accountability', South African Journal of Education 25(3), 139-147.

Progress in International Literacy Study, 2006, PIRLS 2006 International report. South African children's reading literacy achievement, Centre for Evaluation and Assessment, University of Pretoria International report, Pretoria, viewed 22 March 2018, from https://pirls.bc.edu/pirls2006/index.html

Progress in International Literacy Study, 2011, PIRLS 2011 International report. South African children's reading literacy achievement, Centre for Evaluation and Assessment, University of Pretoria International report, Pretoria, viewed 07 April 2018, from https://pirls.bc.edu/pirls2011/index.html

Progress in International Literacy Study, 2016, PIRLS 2016 International report. South African children's reading literacy achievement, Centre for Evaluation and Assessment, University of Pretoria, International report, Pretoria, viewed 07 February 2019, from https://pirls.bc.edu/pirls2016/index.html
Raman, M., Sharma, S. \& Collins, G., 2013, Communication for engineers, Oxford University Press, Cape Town.

Rule, P. \& Land, S., 2017, 'Finding the plot in South African reading education', Reading \& Writing 8(1), a121. https://doi.org/10.4102/rw.v8i1.121

Saeedeh, K.K., 2013, 'Does reading strategy use predict and correlate with reading achievement of EFL learners?', International Journal of Research Studies in Language Learning 2(2), 29-38. https://doi.org/10.5861/ijrsll.2012.118

Sheorey, R. \& Mokhtari, K., 2001, 'Differences in the metacognitive awareness of reading strategies among native and non-native readers', System 29(2001), 431-449.

Suacillo, C.I.M., Um, S.E., Valasquez, J.M., Villaflres, H.N.R. \& Cequena, M.B., 2016, 'Critical reading strategies, reading comprehension and writing performance of ESL college students: A correlational study', International Journal of Advanced Research 4(9), 610-623. https://doi.org/10.21474/IJAR01/1526

Sousa, V.D. Driesnak, M. \& Costa Mendes, I.A., 2007, 'An overview of research designs relevant to nursing: Part 1: Quantitative research designs', Rev Latino-am Enfermagen 15(3), 502-507. https://doi.org/10.1590/\$0104-11692007000300022

Spaul, N., 2016, 'The unfolding reading crisis: The new PIRLS 2016 results...', viewed 23 February 2020, from https://nicspaull.com/2017/12/05/the-unfoldingreading-crisis-the-new-pirls-2016-results/

Van der Berg, S., 2008, 'How effective are poor schools? Poverty and educational outcomes in South Africa', Studies in Educational Evolution 34(3), 145-154. https://doi.org/10.1016/j.stueduc.2008.07.005

Vaseghi, R., Gholami, R. \& Barjestech, H., 2012, 'Critical thinking: An influential factor in developing English reading comprehension performance', Advances in Asian Social Science 2(1), 401-410.

Usher, E. \& Pajares, F., 2008, 'Sources of self-efficacy in school: Critical review of the literature and future directions', Review of Educational Research 78(4), 751-796. https://doi.org/10.3102/0034654308321456

White, C.J., 2005, Research: A practical guide, Ithuthuko Investments (Publishing), Pretoria.

Wilson, K., Devereux, L., Macken-Horarik, M., \& Trimingham-Jack, C., 2004, 'Reading readings: How students learn to (dis)engage with critical reading', in Transforming Knowledge into Wisdom, the Proceedings of the 2004 International HERDSA Conference, Miri, Sarawak, 04-07 July. Available from http://www.herdsa.org.au/ wp-content/uploads/conference/2004/papers/wilson.pdf

Woolfolk, A., 2013, Educational psychology, 12th edn., Pearson Education, Boston, MA.

Zin, Z., Eng, W.B. \& Rafik-Galea, S., 2012, 'Critical reading ability and its relation to L2 proficiency of Malaysian ESL learners', The Southeast Asian Journal of English Language Studies 20(2), 43-54. http://dx.doi.org/10.17576/3L-2014-2002-04 